\title{
Biosynthesis of the Antibiotic Nisin by Whole Streptococcus lactis Organisms
}

\author{
By A. HURST* \\ Sub-department of Chemical Microbiology Department of Biochemistry, \\ University of Cambridge $\dagger$
}

(Received 13 December 1965)

\begin{abstract}
SUMMARY
A reaction mixture is described consisting of a buffered solution of amino acids, salts, growth factors and glucose in which freshly harvested washed Streptococcus lactis incorporated radioactive tracers and synthesized nisin. Rapid nisin synthesis started after a delay of 30-60 min. but bacteria pre-incubated in the reaction mixture synthesized nisin without delay although the rate of protein synthesis remained the same as that of freshly harvested bacteria. Although growing $S$. lactis is sensitive to penicillin and mitomycin these antibiotics had no effect on nisin synthesis by washed organisms. Actinomycin $D$ inhibited uptake of tritiated uridine immediately and inhibited nisin synthesis after a delay of about $60 \mathrm{~min}$. Antibiotics which interfere with protein synthesis, e.g. chloramphenicol, puromycin and terramycin also interfered with nisin synthesis. The inhibition was immediate and occurred irrespective of whether the antibiotics were added at the beginning of an experiment or after $50 \mathrm{~min}$. Nisin synthesis was more sensitive than protein synthesis. The data suggest that nisin synthesis occurs by a mechanism similar to that of protein synthesis.
\end{abstract}

\section{INTRODUCTION}

Polypeptide antibiotics frequently contain unusual amino acids; some of the constituent amino acids may be in the uncommon $\mathbf{D}$ configuration and at least some part of the molecule is cyclized. The physiological function of these substances is unknown. In the last few years the methods by which micro-organisms synthesize these unusual substances have interested many workers. Mach, Reich \& Tatum (1963) and Mach \& Tatum (1964) studied the synthesis of tyrocidine; the biosynthesis of polymyxin was studied by Paulus \& Gray (1964); gramicidin S by Eikhom et al. (1963, 1964), Winnick, Lis \& Winnick (1961); gramicidine by Okuda, Edwards \& Winnick (1963); bacitracin by Bernlohr \& Novelli (1963), Snoke (1961), Cornell \& Snoke (1964), and Shimura, Sasaki \& Sugawara (1964); mycobacillin by Banerjee \& Bose (1964) and actinomycin by Katz (1960), Katz \& Weissbach (1962), (1963) and Katz, Wise \& Weissbach (1965). The conclusion reached by most of these workers is that polypeptide antibiotics are synthesized non-ribosomally; two recent studies with cell-free systems which synthesize gramicidin $\mathbf{S}$ further support this idea (Berg, Frøholm, \& Laland, 1965; Yukioka et al. 1965).

However, Winnick and collaborators found that biosynthesis of gramicidin S,

* Formerly A. Hirsch.

$\dagger$ Present address: Unilever Research Laboratory, Colworth House, Sharnbrook, Bedford. 
tyrocidine and gramicidin by whole organisms was prevented by inhibitors of protein synthesis (Winnick et al. 1961; Winnick \& Winnick, 1961; Okuda et al. 1963; Uemura, Bodley, Adiga \& Winnick, 1965). Later work with cell-free systems showed that ribosomes were essential for the synthetic process (Uemura, Okuda \& Winnick, 1963; Bodley et al. 1964). Recently Winnick and co-workers isolated a gramicidin S 'messenger RNA' and determined some of its physical and chemical properties (Hall et al., 1965; Sedat \& Hall, 1965). These results suggest that gramicidin $\mathrm{S}$ is synthesized by a process similar to that of normal protein synthesis.

Synthesis of the polypeptide antibiotic nisin was of interest because it is not made by a Bacillus but by Streptococcus lactis (Mattick \& Hirsch, 1947) and it appears to have an unusually large molecular weight (Chesseman $\&$ Berridge, 1959). Nisin is used in practice as a food preservative (Hawley, 1957; Gibbs \& Hurst, 1964). The name 'nisin' describes a family of antibiotics, at least four of which have been partially characterized (Berridge, Newton \& Abraham, 1952). Different strains of $S$. lactis are also known which produce different antibiotics (Hirsch \& Grinsted, 1951; Hirsch, $1951 b$ ). The composition of nisin A was determined by Cheeseman \& Berridge (1959); it contains 55 amino acid residues and the unusual amino acids lanthionine and $\beta$-methyllanthionine, but the optical configuration and sequence of amino acids are not known; it has no free terminal carboxyl or amino groups. Cheeseman \& Berridge estimated the molecular weight of nisin A to be about 7000; this figure has recently been challenged by Bodansky \& Perlman (1964). If the original estimate is correct, nisin, which is considered to be a polypeptide may be more complex than some of the small proteins, e.g. insulin, which has a molecular weight of 6000 (Sanger, 1959).

In the work described in this paper whole organisms of Streptococcus lactis were used to try to decide whether the synthesis of nisin is an enzymic or ribosomal process. The complex nutritional requirements and the vigorous acid production of this organism made it desirable to work with washed bacteria suspended in a reaction mixture of defined composition and, as far as possible, constant $\mathrm{pH}$ value. The effects produced by inhibitors of the synthesis of mucopeptides, protein, RNA and DNA (for review see Gale, 1963) suggest that the main mechanism concerned in nisin synthesis is similar to that of normal protein synthesis.

\section{METHODS}

Organisms. For nisin production Streptococcus lactis 354/07 (NCDo 497) was used. For nisin bioassay $S$. cremoris strain 1 P5 (NCDo 495) was used.

Media and culture conditions. The organisms were subcultured daily in a medium of the following composition $(\%, \mathrm{w} / \mathrm{v})$ : meat extract (Lemco), 1 ; yeast extract (Difco), 1; tryptone (Difco), 1 ; glucose, $1 ; \mathrm{NaCl}, 0.5 ; \mathrm{Na}_{2} \mathrm{HPO}_{4}, 0.2 ; \mathrm{pH} \mathrm{7.0.} \mathrm{In-}$ cubation was at $25^{\circ}$ in deep tubes without shaking. Stock cultures were stored at $4^{\circ}$ on slopes of the same medium with $1.5 \%(\mathrm{w} / \mathrm{v})$ agar. New slopes were started at fortnightly intervals.

For preparing washed suspensions of Streptococcus lactis strain 354/07 the high nisin yielding medium of Hirsch (1951 $a$ ) was used (medium 22). It contained (\%, $\mathrm{w} / \mathrm{v})$ : meat extract, 1 ; peptone (Evans), 1 ; glucose, $2.5 ; \mathrm{Na}$ acetate, $1.5 ; \mathrm{Na}$ citrate, $1.5 ; \mathrm{Na}_{2} \mathrm{HPO}_{4}, 0.5$; and $\mathrm{Ca}$ pantothenate $1 \mu \mathrm{g} . / \mathrm{ml}$. 
Chemicals. A.R. grade reagents were used. (U-14 C)-L-glutamic acid $(6,4 \mathrm{mc} / \mathrm{mm}$ ), $\left(\mathrm{G}-{ }^{-3} \mathrm{H}\right)$-DL-threonine $\left(66 \mathrm{mc} / \mathrm{mm}\right.$ and $\left(5,6-{ }^{3} \mathrm{H}\right)$ uridine $(22 \mathrm{c} / \mathrm{mm})$ were purchased from the Radiochemical Centre, Amersham, Buckinghamshire. Penicillin, chloramphenicol, puromycin, terramycin and mitomycin were gifts from members of the department. Actinomycin D was a gift from Messrs Merck, Sharpe \& Dohme, U.S.A.

Reaction mixture. The synthesis of nisin, incorporation of amino acids and protein synthesis were followed in a reaction mixture containing all the known growth requirements of Streptococcus lactis. This mixture contained amino acid mixture A $(1.0 \mathrm{ml}),. 10 \%(\mathrm{w} / \mathrm{v})$ glucose $(1.0 \mathrm{ml}$.), buffered salts solution $\mathbf{B}(1.0 \mathrm{ml}$.) purine + pyrimidine mixture $\mathrm{C},(0.1 \mathrm{ml}$.), vitamin mixture $\mathrm{D}(0.1 \mathrm{ml}$.$) , tracer amino acids,$ bacteria equiv. $1 \mathrm{mg}$ dry weight $/ \mathrm{ml}$. and inhibitors as required; total volume made to $10 \mathrm{ml}$. with distilled water. These various solutions had the following compositions. Amino acids, purines and pyrimidines were made up according to Gale \& Folkes (1953). Amino acid mixture A contained each of the following at $2 \mathrm{mg} . / \mathrm{ml}$.: glycine, L-aspartic acid, tyrosine, tryptophan, phenylalanine, histidine, lysine, arginine, methionine proline, hydroxyproline, serine, cysteine, cystine, alanine, leucine, isoleucine and valine, the solution being adjusted to $\mathrm{pH} 7 \cdot 0$ with $2 \mathrm{~N}-\mathrm{NaOH}$. L-Glutamic acid and DL-threonine were made up as separate solutions at $2 \mathrm{mg} . / \mathrm{ml}$. and diluted 1/10 for use. (U-14C)-L-glutamic acid was used at $50 \mu \mathrm{g} . / \mathrm{ml}$. with a specific activity of $2 \mu \mathrm{c} / \mathrm{mg}$. (G- ${ }^{3} \mathrm{H}$ )-DL-threonine was used at $100 \mu \mathrm{g} . / \mathrm{ml}$. with a specific activity of $30 \mu \mathrm{c} / \mathrm{mg}$. Buffered salt solution $\mathrm{B}$ contained $(\%, \mathrm{w} / \mathrm{v}): 1, \mathrm{KH}_{2} \mathrm{PO}_{4} ; 3 \cdot 3, \mathrm{Na}_{2} \mathrm{HPO}_{4}$; 1 , NaCl; $0.7, \mathrm{MgSO}_{4} .7 \mathrm{H}_{2} \mathrm{O} ; 15$, trisodium citrate. Purine + pyrimidine mixture $\mathrm{C}$ contained adenine, xanthine, hypoxanthine, guanine, thymine, cytosine, uracil, each at $1 \mathrm{mg} . / \mathrm{ml}$. The vitamin mixture $\mathrm{D}$ was made up according to Niven (1944), and contained riboflavin, Ca-pantothenate, nicotinic acid, pyridoxine (each at $1 \mathrm{mg} . / \mathrm{ml}$.) thiamine $(0.1 \mathrm{mg} . / \mathrm{ml}$.) and biotin $1 \mu \mathrm{g} . / \mathrm{ml}$.

Suspensions of organisms. Medium 22 was inoculated $(10 \%, v / v)$ with an overnight culture of Streptococcus lactis $354 / 07$, incubated at $30^{\circ}$, and the growth of the culture followed by its acid production. When the $\mathrm{pH}$ value had decreased to $6 \cdot 0-5 \cdot 8$ (after about $6 \mathrm{hr}$ ) the organisms were harvested on the centrifuge, washed once with buffered salts solution $B$ and finally suspended in distilled water at equiv. $10 \mathrm{mg}$. dry wt $/ \mathrm{ml}$.; $1.0 \mathrm{ml}$. of this suspension was used in $9 \mathrm{ml}$. reaction mixture. The dry weight of bacterial suspensions was estimated turbidimetrically with a Hilger spectrophotometer calibrated for the organism. Incubations were done at $30^{\circ}$.

Preparation of samples. For estimating nisin by bioassay the reaction was stopped by adding $10 \mathrm{~N}-\mathrm{HCl}$ to bring the sample to $\mathrm{pH} 1 \cdot 8-2 \cdot 0$; the tubes were then placed in a boiling-water bath for $5 \mathrm{~min}$. and then centrifuged at $5000 \mathrm{~g}$ for $10 \mathrm{~min}$; at $\mathrm{pH} \mathrm{1 \cdot 8-2 \cdot 0} \mathrm{nisin} \mathrm{is} \mathrm{stable} \mathrm{and} \mathrm{remains} \mathrm{entirely} \mathrm{in} \mathrm{the} \mathrm{supernatant} \mathrm{fluid} \mathrm{(Hirsch,}$ $1951 a)$.

For estimating radioactivity and protein, the reaction was stopped by diluting with an equal vol. of cold $10 \%$ trichloroacetic acid (TCA).

For radioactivity estimations with a 'Panax' end-window Geiger counter (taking at least 300 counts) and the samples were prepared as described by Park \& Hancock (1960). For estimations with a Nuclear Chicago liquid scintillation counter (System 724) TCA precipitates were filtered on 2-cm. membranes (Oxoid, London), washed 
successively with 5 and $1 \%$ acetic acid and finally with distilled water. The membranes were put into glass vials ( $\frac{1}{2} \mathrm{in} . \times 2 \mathrm{in}$.), dried at $105^{\circ}$ for $2 \mathrm{hr}$ and then covered by $2.5 \mathrm{ml}$. toluene scintillation fluid $(3.5 \mathrm{~g}$. PPO, 2:5-diphenyloxazole, and $50 \mathrm{mg}$. POPOP, 1:4-bis-2-(4-methyl-5-phenyloxazolybenzene) in $1 \mathrm{l}$. toluene). The vials were then closed, placed in carrier bottles and counted to 10,000 counts or 4 min., whichever was quicker.

Fractionation of bacteria was done according to the method of Park \& Hancock (1960).

Protein was estimated by the Lowry modification of the Folin \& Ciocalteau method (Lowry et al. 1951).

Bioassay of nisin. The turbidimetric method of Berridge \& Barrett (1952) modified to increase its sensitivity was used as the basis of the present method with which $1 \mathrm{~m} \mu \mathrm{g}$. nisin/ml. could be estimated with an accuracy of $\pm 15 \%$. Each result reported in this paper represents the average of at least three independent assays. The method was as follows.

Overnight cultures of the test organism Streptococcus cremoris (1 P5) were diluted with fresh medium and incubated at $30^{\circ}$ for $1 \mathrm{hr}$. This step was repeated 2-3 times to get a vigorously growing culture; when a 1/10 dilution of such a culture had an extinction value of $0 \cdot 1$ at $600 \mathrm{~m} \mu$ (in the Unicam S.P. 500 spectrophotometer) it was used to inoculate $(1 \%, v / v)$ a 1-l. volume of the same medium which was incubated for $1 \mathrm{hr}$ at $30^{\circ}$ (culture A). A volume $(0 \cdot 1 \mathrm{ml}$.) of sample containing nisin was added to $10 \mathrm{ml}$. of culture $\mathbf{A}$ and further dilutions in culture $\mathbf{A}$ were made as quickly as possible; the tubes were then incubated for $2 \frac{1}{2} 3 \mathrm{hr}$ at $30^{\circ}$. Growth was stopped by injecting into each tube $\mathbf{0 . 1} \mathrm{ml}$. of $\mathbf{0 . 0 0 4} \%$ solution of thiomersalate (Berridge \& Barrett, 1952). The extinction was measured in an S.P. 500 Unicam spectrophotometer at $600 \mathrm{~m} \mu$. Sterile precautions were unnecessary after the culture stages. A series of standards were set up in triplicate for each assay and values for the unknown samples were read from the curve. Figure 1 shows an example of the growth response curve obtained.

Nisin standard. A gift of purified nisin was received from Dr J. Tramer (United Dairies Central Laboratories, London). Dr B. Giles (Unilever Research Laboratory, Sharnbrook, Bedford) examined this material in a Spinco Analytical Ultracentrifuge Model $\mathbf{E}$ and reported that it behaved as a single substance. This purified nisin was further examined by high voltage paper electrophoresis (Shandon, London). Up to $1 \mathrm{mg}$. nisin/spot was used; the nisin spot did not give a ninhydrin reaction but the histidine residue which nisin contains was used to locate it with Pauly's reagent (Dent, 1947). The nisin spot was also located by bio-electrophoretograms. Neither test showed more than one spot. On the basis of the ultracentrifuge and electrophoretic data the sample was assumed to be pure nisin and the results of assays were expressed as $\mu \mathrm{g} . / \mathrm{ml}$. in terms of this standard. The relationship of this material to the nisins A, B, C and D of Berridge et al. (1952) is not known. The nisin standard was dissolved at $100 \mu \mathrm{g} . / \mathrm{ml}$. in $0.05 \mathrm{~N}-\mathrm{HCl}$, dispensed in $0.1 \mathrm{ml}$. volumes in $15 \mathrm{ml}$. vials and stored frozen. For assay $10 \mathrm{ml}$. of $0.01 \mathrm{~N}-\mathrm{HCl}$ was added to each vial and $0.1 \mathrm{ml}$. of the solution added to $10 \mathrm{ml}$. of culture $\mathbf{A}$; further dilutions were then made. The first tube of the standard series thus contained $10 \mathrm{~m} \mu \mathrm{g}$. nisin $/ \mathrm{ml}$. and usually did not become turbid during the assay period.

Precautions. Many of the assays described below involved the estimation of nisin 
in the presence of other antibiotics. Penicillin, oxamycin and terramycin introduced no complications since they were inactivated by the treatment $\left(5 \mathrm{~min}\right.$. at $100^{\circ}$ at $\mathrm{pH} \mathbf{1 \cdot 8 - 2 \cdot 0 )}$ used for the extraction of nisin. Other antibiotics, particularly chloramphenicol, resisted this treatment and preliminary experiments were run to determine the maximum concentration at which these substances could be used without subsequently affecting the nisin assay. For example, the maximum permissible concentration of chloramphenicol in a reaction mixture was $20 \mu \mathrm{g} . / \mathrm{ml}$.

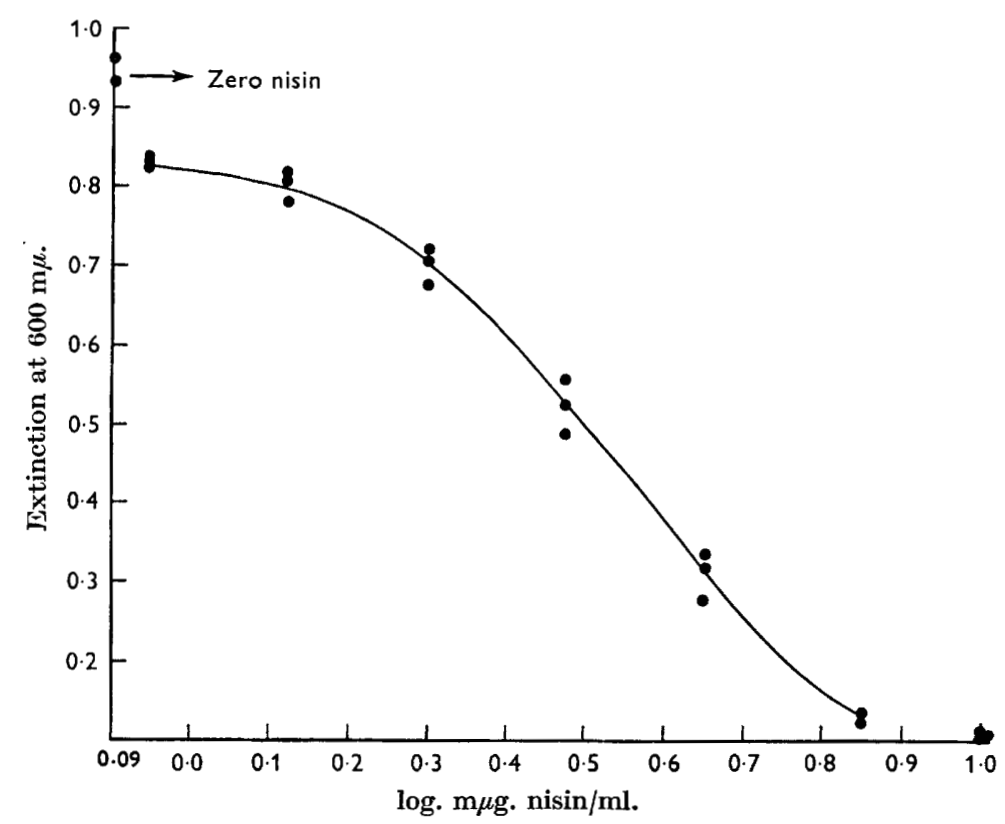

Fig. 1. Growth/response of standard in bioassay of nisin.

\section{RESULTS}

Time course of nisin synthesis

Washed Streptococcus lactis organisms grew slowly and synthesized nisin at an accelerating rate in the reaction mixture (Fig. 2). During the 120 min. experimental period the $\mathrm{pH}$ value remained above 6.0 , dry wt. increased from 1.0 to $1.55 \mathrm{mg} . / \mathrm{ml}$., protein increased from 555 to $853 \mu \mathrm{g}$. $/ \mathrm{ml}$., and the protein content of the bacteria remained approximately constant at $55 \%$. The nisin content increased from about $1 \mu \mathrm{g} . / \mathrm{ml}$. to about $15 \mu \mathrm{g} . / \mathrm{ml}$. during the same period. The rates of protein synthesis and nisin synthesis were not linear; the rates increased particularly after $60 \mathrm{~min}$. (Fig. 2). The total amount of nisin synthesized by suspensions of organisms prepared on different days varied considerably; at the end of the experimental period (120 min.) the nisin content ranged from 0.2 to $5 \%$ of the dry wt. of organism.

In another experiment a suspension of bacteria was divided into two equal volumes; one portion was incubated for $100 \mathrm{~min}$. in the reaction mixture and then resuspended in fresh reaction mixture. Nisin synthesis and the incorporation of tritiated threonine of the pre-incubated and freshly harvested organisms were then 
compared. The results (Fig. 3) showed that threonine was incorporated at the same rate by the two suspensions, but that nisin synthesis was more rapid in the preincubated bacteria and occurred without lag.

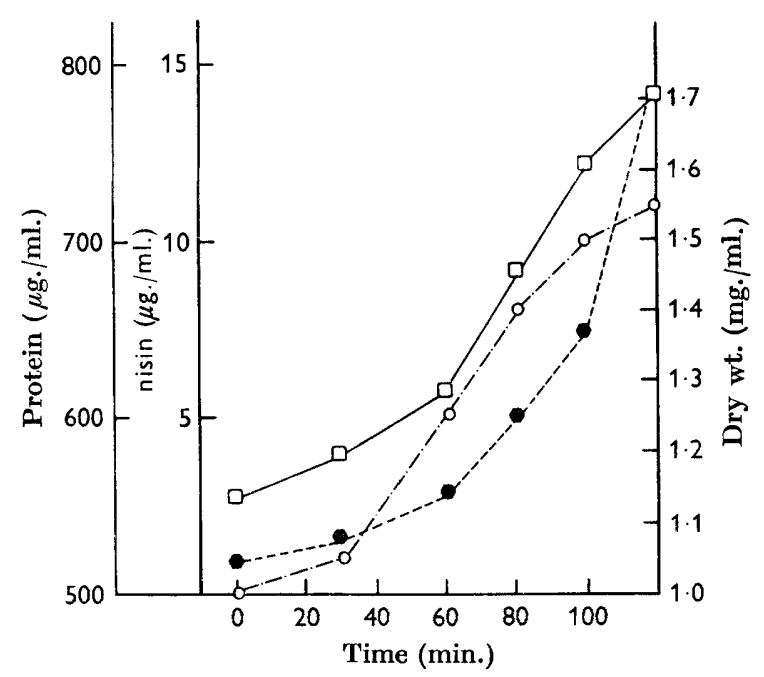

Fig. 2

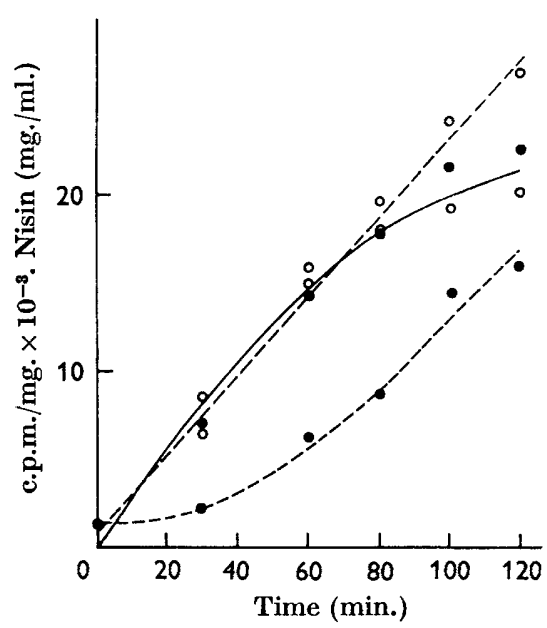

Fig. 3

Fig. 2. Changes in dry weight, protein and nisin synthesis of a washed suspension of Streptococcus lactis in the reaction mixture. Protein, $\square-$; dry weight, $\mathrm{O}_{-} \cdot-\cdot$; nisin, - - -

Fig. 3. Nisin synthesis and incorporation of $\left[\mathrm{G}^{3}{ }^{3} \mathrm{H}\right]-\mathrm{DL}-$ threonine in freshly harvested and pre-incubated Streptococcus lactis organisms. Radioactivity, __; nisin - - ; fresh organisms, ; pre-incubated organisms, $O$.

\section{Incorporation of amino acids}

The reaction mixture with organisms was incubated for $60 \mathrm{~min}$. and the bacteria then fractionated by the method of Park \& Hancock (1960). With (U-14C)-Lglutamic acid $62 \%$ of the radioactivity was found in the fraction liberated by trypsin digestion; $28 \%$ was in the insoluble residue; and the remaining $10 \%$ was distributed between the nucleic acid and ethanol-soluble fractions. Glutamic acid does not specifically label the protein of Streptococcus lactis and was used only in early experiments on time-course studies with inhibitors of protein synthesis (e.g. as in Fig. 4). In later experiments protein was estimated by the Lowry et al. method or by incorporation of $\left(\mathrm{G}-{ }^{3} \mathrm{H}\right)$-DL-threonine. Fractionation of bacteria incubated with labelled threonine showed that $88 \%$ of the radioactivity was in the trypsindigestible fraction.

\section{Effect of the antibiotics penicillin and cycloserine}

Growing cultures of Streptococcus lactis are sensitive to penicillin; $0.05 \mu \mathrm{g} . / \mathrm{ml}$. causes inhibition in overnight growth tests (minimal inhibitory concentration, m.i.c., $=0.05 \mu \mathrm{g} . / \mathrm{ml}$.). Concentrations of penicillin up to $2 \mu \mathrm{g} . / \mathrm{ml}$. were without effect on nisin synthesis and incorporation of DL-threonine when tested in the reaction mixture; the time of addition of the antibiotic was also unimportant. Oxamycin which was tested up to $100 \mu \mathrm{g}$. $/ \mathrm{ml}$. was also without effect. 


\section{Inhibitors of protein synthesis}

Incorporation of $\left(\mathrm{U}^{14} \mathrm{C}\right)$-L-glutamic acid and nisin synthesis were measured in time-course experiments, with and without inhibitors. Chloramphenicol has an m.i.c. of 5-10 $\mu \mathrm{g} . / \mathrm{ml}$. and was tested at 5, 10 and $20 \mu \mathrm{g} . / \mathrm{ml}$. Results of a typical experiment in which chloramphenicol was added at time 0 or at 50 min. are shown in Fig. 4. Addition of chloramphenicol at time 0 caused a $94 \%$ inhibition of glutamic acid incorporation and $100 \%$ inhibition of nisin synthesis. When chloramphenicol was added at $\mathbf{5 0} \mathrm{min}$. further nisin synthesis was completely halted, but incorporation of glutamic acid continued at a slower rate. In similar experiments puromycin (m.i.c. about $30 \mu \mathrm{g} . / \mathrm{ml}$.) at $50 \mu \mathrm{g} . / \mathrm{ml}$. and terramycin (m.i.c. 0.5-1 $\mu \mathrm{g} . / \mathrm{ml}$.) at $1 \mu \mathrm{g} . / \mathrm{ml}$. gave results similar to those obtained with chloramphenicol.

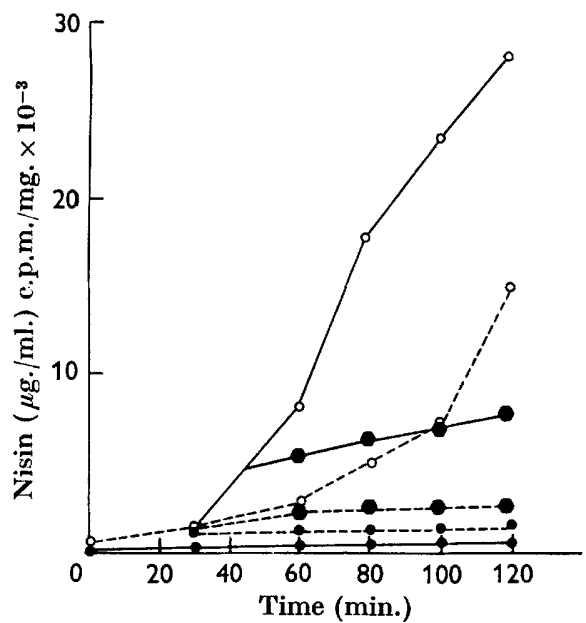

Fig. 4

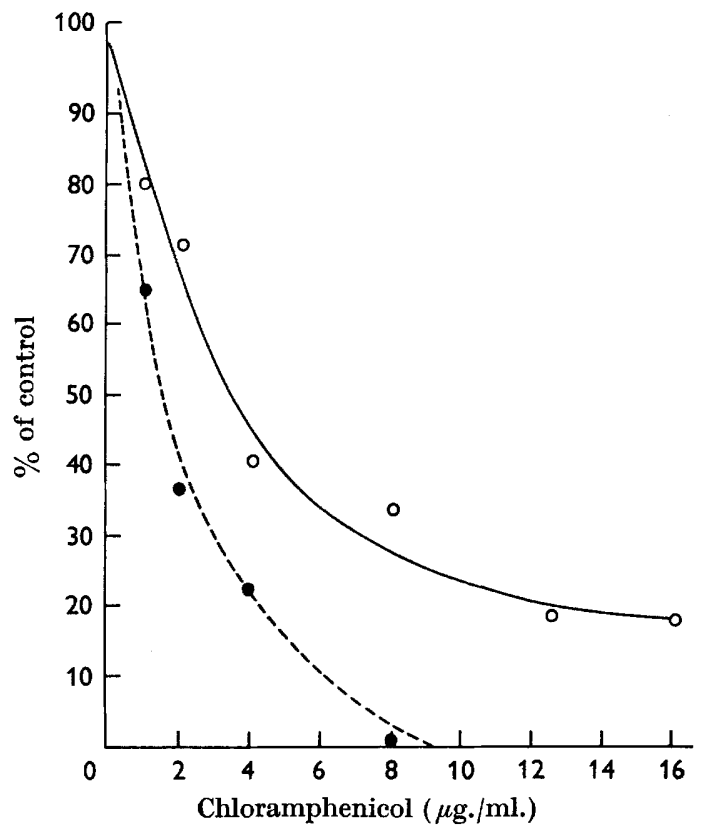

Fig. 5

Fig. 4. The effect of chloramphenicol $(20 \mu \mathrm{g}$. ml.) on nisin synthesis and incorporation of [U-14C]-L-glutamic acid by Streptococcus lactis. Radioactivity, __; nisin; - .-; control, $O$; chloramphenicol added at time zero, $\bigcirc$; at $50 \mathrm{~min}$.

Fig. 5. Protein and nisin synthesis by Streptococcus lactis in the presence of various concentrations of chloramphenicol, as $\%$ of control without antibiotic. Protein, $\mathrm{O}-$; nisin,

The controls shown in Figs. 2-4 all have the common feature that the rate of nisin synthesis increased after a lag of 30-60 min. To compare the action of antibiotics on protein and nisin synthesis, inhibitors were added after $60 \mathrm{~min}$. to avoid this lag period: $20 \mathrm{ml}$. of the reaction mixture were incubated for $60 \mathrm{~min}$. at $30^{\circ}$ and then subdivided into $2 \mathrm{ml}$. portions containing a range of concentrations of inhibitors or with distilled water as a control. Incubation at $30^{\circ}$ was continued for another hour and the protein (by method of Lowry et al.) and the nisin content 
estimated. The increase in protein and nisin between 60 and $120 \mathrm{~min}$. in the control tube was taken as $100 \%$ and the effect of inhibitors was expressed as a $\%$ of the control. Typical results obtained with the same three inhibitors are shown in Figs. 5,6 and 7 . In each case concentrations of inhibitor well below the m.i.c. were used. In all three cases the antibiotic was a more effective inhibitor of nisin synthesis than of protein synthesis. At an antibiotic concentration of one-tenth m.i.c. nisin synthesis was more sensitive than protein synthesis by a factor of 2 for chloramphenicol, $3 \cdot 3$ for terramycin and 10 for puromycin.

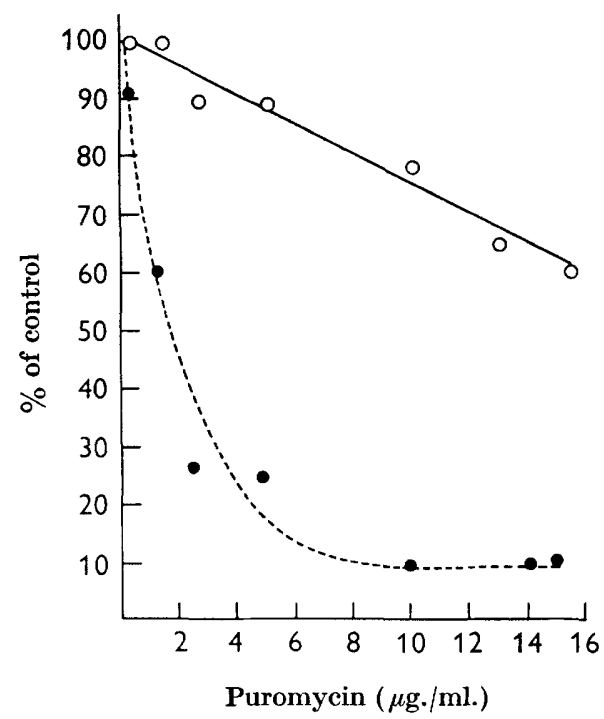

Fig. 6

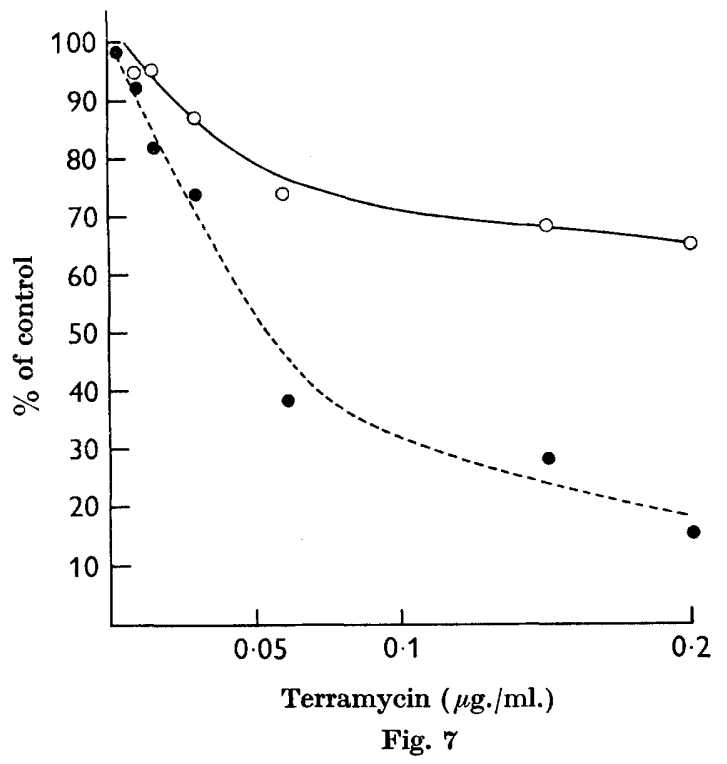

Fig. 7

Fig. 6. Protein and nisin synthesis by Streptococcus lactis in the presence of various concentrations of puromycin, as $\%$ of control without antibiotic. Protein, $\mathrm{O}$-; nisin, - - ..

Fig. 7. Protein and nisin synthesis of $S$. lactis in the presence of various concentrations of terramycin, as $\%$ of control without antibiotic. Protein, $\mathrm{O}-$, nisin,

\section{Inhibitors of nucleic acid synthesis}

Further time-course studies were made with mitomycin which inhibits DNA strand separation (Iyer \& Szybalski, 1963). Nisin synthesis was insensitive to mitomycin $(0.5 \mu \mathrm{g} . / \mathrm{ml}$.) although growth was inhibited by $0.03 \mu \mathrm{g} . / \mathrm{ml}$., the lowest concentration tested.

Actinomycin D, an inhibitor of RNA synthesis (Kirk, 1960; Hurwitz et al. 1962) was used at $10 \mu \mathrm{g} . / \mathrm{ml}$. In the $120 \mathrm{~min}$. experimental period it had no effect on nisin synthesis when added at 60 min., but nisin synthesis was halted after $80 \mathrm{~min}$. when the antibiotic was added at zero time. This experiment was repeated with tritiated uridine ( $1 \mu \mathrm{c} . / \mathrm{ml}$. reaction mixture) to assess the inhibition of RNA synthesis. In the first of such experiments (Fig. 8) the added isotope was all taken up by the control bacteria in the first $20 \mathrm{~min}$. During the same period there was insignificant incorporation by the actinomycin-treated bacteria. Nisin synthesis in the control followed a linear course for $80 \mathrm{~min}$., as in the previous experiment, and then increased. The actinomycin-treated culture synthesized nisin at a rate $60 \%$ that of 
the control for $60 \mathrm{~min}$, after which time nisin synthesis ceased altogether. In another similar experiment no nisin was synthesized during the first $40-60 \mathrm{~min}$. and actinomycin completely blocked subsequent nisin synthesis; uptake of tritiated uridine was also inhibited (Fig. 9).

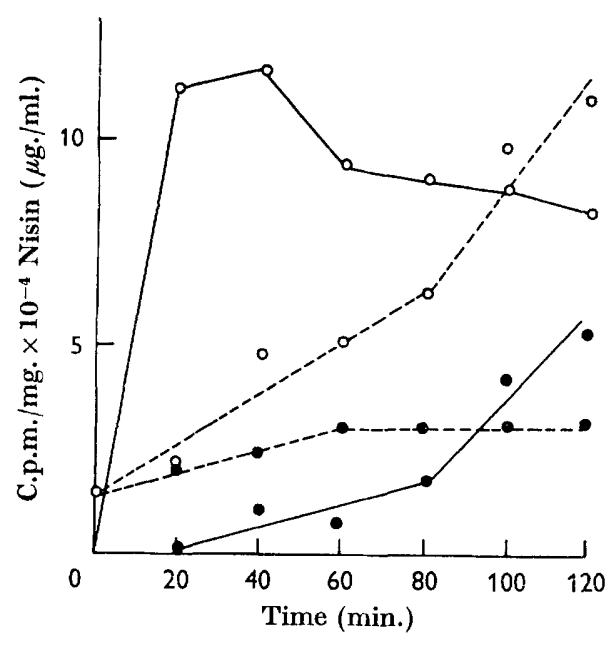

Fig. 8

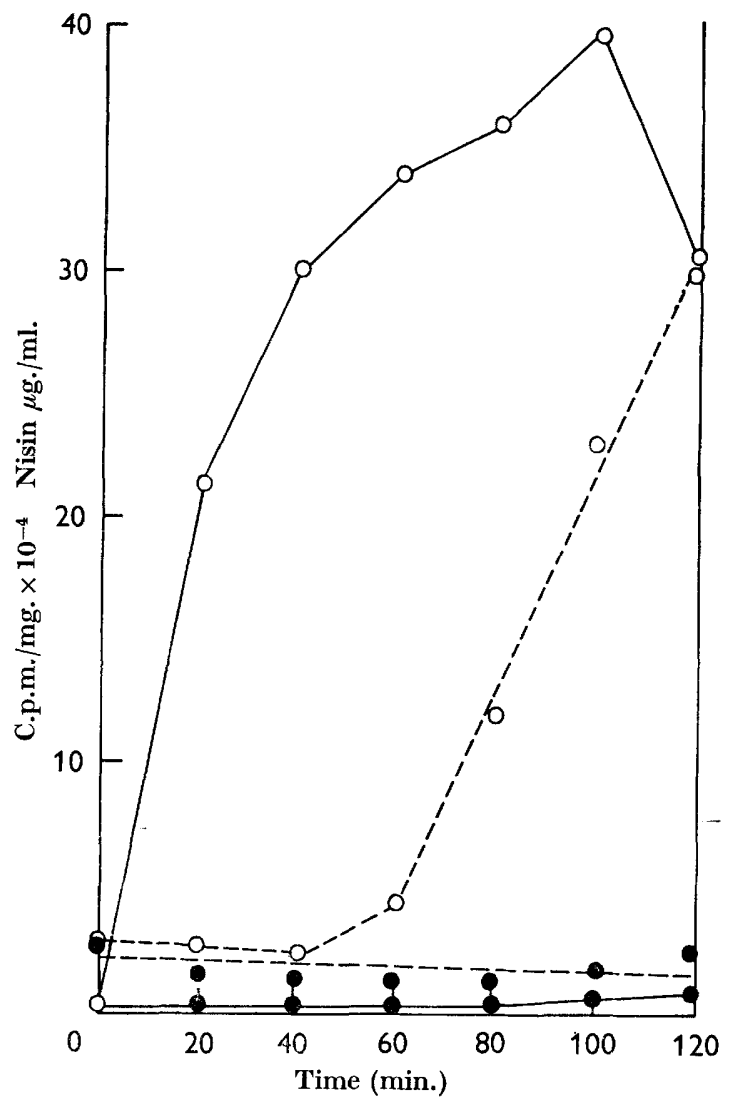

Fig. 9

Fig. 8. The effect of actinomycin $\mathrm{D}(10 \mu \mathrm{g} . / \mathrm{ml}$. $)$ added at time 0 on nisin synthesis and incorporation of $\left[5,6{ }^{3} \mathrm{H}\right]$-uridine by a suspension of Streptococcus lactis already synthesizing nisin. Radioactivity, - - ; nisin, - - ; control, $O$; actinomycin-D treated,

Fig. 9. As Fig. 8 but this suspension of $S$. lactis was not synthesizing nisin during the first 40 min. Radioactivity, - ; nisin, -..; control, $O$, actinomycin-D treated,

\section{DISCUSSION}

The evidence put forward in this paper favours the view that the major part of nisin synthesis occurs by a mechanism similar to that of normal protein synthesis. This view is based on the effect of inhibitors of protein synthesis (chloramphenicol, puromycin, terramycin) which also inhibited nisin synthesis. The effect observed might have been due either to nisin being synthesized ribosomally or to an indirect effect of the inhibitors on the formation of the enzymes concerned in nisin formation. In every case, therefore, the inhibitors were also tested under conditions when it 
might be expected that the nisin-synthesizing enzymes were already formed. However, under these conditions there was also an immediate halting of nisin synthesis.

Actinomycin $\mathbf{D}$ when added early in the experiment inhibited RNA synthesis and nisin synthesis, suggesting that, as in the normal protein synthesis mechanism, messenger RNA is also involved in nisin synthesis. The results shown in Fig. 8 suggest that this RNA may have an unusually long half-life. The lack of effect of mitomycin suggests that the synthesis of nisin does not depend on newly formed DNA and that the code was already in the bacteria when they were harvested for experiment.

Penicillin did not inhibit nisin synthesis; cycloserine (oxamycin), an antibiotic known to interfere specifically with wall mucopeptide synthesis in Staphylococcus aureus (Strominger, 1962) was without effect on nisin synthesis. It does not appear likely that nisin is connected with the wall mucopeptide of the organism.

At present there is controversy about the mechanism of synthesis of gramicidin $\mathbf{S}$ which may be made ribosomally (Hall et al. 1965) or by some other means (Berg et al. 1965; Yukioka et al. 1965). However, the molecular weight of gramicidin $\mathrm{S}$ is only about 1350 according to Bodansky \& Perlman (1964). A final proof that nisin is made ribosomally must await the development of a cell-free system derived from Streptococcus lactis as has been done with Bacillus brevis (Uemura et al. 1963; Okuda et al. 1964; Berg et al. 1965; Yukioka et al. 1965). The state of the organisms at the time of harvesting may be critical for preparations of this nature. For example, Fig. 3 here shows that freshly harvested bacteria and bacteria which had been incubated in the reaction mixture made protein at the same rate; the rate of nisin synthesis by the two suspensions was, however, very different. In the first $30 \mathrm{~min}$. the preincubated bacteria made $6 \mu \mathrm{g}$. nisin $/ \mathrm{ml}$. reaction mixture and the freshly harvested bacteria made $1.2 \mu \mathrm{g}$. nisin/ml. reaction mixture. There is no simple explanation for this observation. It is also difficult to understand why, if nisin is made as other proteins on ribosomes, its synthesis should be more sensitive to chloramphenicol, puromycin and terramycin than other proteins (see, for example, Figs. 5, 6, 7). However, similar results have already been reported, for example, the preferential inhibition of $\beta$-galactosidase synthesis in Escherichia coli by chloramphenicol (Sypherd \& Strauss, 1963) and puromycin (Sells, 1965) and of ornithine transcarbamylase synthesis by chloramphenicol (Browne \& Rogers, 1963).

This work was done while the author was on a year's study leave from Unilever Research Laboratory, Sharnbrook, Bedford. Thanks are due to the Senior Management, Unilever Limited, who made this arrangement possible. Thanks are also due to members of the sub-department of Chemical Microbiology for many helpful discussions and Dr J. Tramer of United Dairies Central Laboratory, London, for a gift of pure nisin.

\section{REFERENCES}

Banerjee, A. B. \& Bose, S. K. (1964). Biosynthesis of mycobacillin, a new antifungal peptide. J. Bact. 87, 1397.

Berg, T. L. Frøholm, L. O. \& Laland, S. G. (1965). The biosynthesis of gramicidin S in a cell-free system. Biochem. J. 96, 43.

Bernlohr, R. W. \& Novelli, G. D. (1963). Bacitracin biosynthesis and spore formation: The physiological role of an antibiotic. Arch. Biochim. Biophys. 103, 94. 
Berridge, N. J. \& Barrett, J. (1952). A rapid method for the turbidimetric assay of antibiotics. J. gen. Microbiol. 6, 14.

Berridge, N. J. \& Newton, G. G. F. \& Abraham, E. P. (1952). Purification and nature of the antibiotic nisin. Biochem. J. 52, 529.

Bodansky, M. \& Perlman, D. (1964). Are peptide antibiotics small proteins? Nature, Lond. 204, 840.

Bodley, J. W., Uemura, I., Adiga, P. R., Okuda, K. \& Winnick, T. (1964). Participation of ribosomes in the biosynthesis of gramicidins and tyrocidines. Biochemistry, $\mathbf{3}$, 1492.

Browne, S. W. \& Rogers, P. (1963). Accumulation of repressor for ornithine transcarbamylase synthesis in Escherichia coli mediated by chloramphenicol. Biochim. Biophys. Acta, 76, 600.

Cheeseman, G. C. \& Berridge, N. J. (1959). Observations on the molecular weight and chemical composition of nisin A. Biochem. J. 71, 185.

Connell, N. \& Snoke, J. E. (1964). Biosynthesis of bacitracin and protein. Biochim. Biophys. Acta, 91, 533.

Dent, C. E. (1947). The amino-aciduria in Fanconi syndrome. Biochem. J. 41, 240.

Erкhom, T. S., Jonsen, J., Laland, S. \& Refsvix, T. (1963). On the biosynthesis of gramicidin S. Biochim. Biophys. Acta, 76, 465.

Eikhom, T. S., Jonsen, J., Laland, S. \& Refsvik, T. (1964). Studies on the biosynthesis of gramicidin $\mathrm{S}$ in whole cells of Bacillus brevis. Biochim. Biophys. Acta, 80, 648.

Gale, E. F. (1963). Mechanism of antibiotic action. Pharmacol. Rev. 15, 481.

Gale, E. F. \& Folkes, J. P. (1953). The assimilation of amino-acids by bacteria. 14. Nucleic acid and protein synthesis in Staphylococcus aureus. Biochem. J. 53, 483.

GibBs, B. M. \& HuRst, A. (1964). Limitations of nisin as a preservative in non-dairy foods. In Microbial Inhibitors in Food ed. by N. Molin, p. 151. Stockholm: Almqvist and Wiksell.

Hall, J. B., Sedat, J. W., Amiga, P. R., Uemura, I. \& Winnick, T. (1965). Gramicidin S messenger RNA. I. Isolation and characterization. J. mol. Biol. 12, 162.

Hawley, H. B. (1957). Nisin in food technology. Fd Mf. 32, 430.

Hirsch, A. (1951 $a$ ). Growth and nisin production of a strain of Streptococcus lactis. J. gen. Microbiol. 5, 208.

Hirsch, A. $(1951 b)$. Various antibiotics from one strain of Streptococcus lactis. Nature, Lont. 167, 1031.

Hirsch, A. \& Grinsted, E. (1951). The differentiation of the lactic streptococci and their antibiotics. J. Dairy Res. 18, 198.

Hurowitz, J., Furth, J. J., Maramy, M. \& Alexander, M. (1962). The role of deoxyribonucleic acid in ribonucleic acid synthesis. III. The inhibition of enzymatic synthesis of ribonucleic acid and deoxyribonucleic acid by Actinomycin D and proflavin. Proc. natn. Acad. Sci. U.S.A. 48, 1222.

Iyer, V. N. \& Szybalski, W. (1963). A molecular mechanism for mitomycin action: linking of complementary DNA strands. Proc. natn. Acad. Sci. U.S.A. 50, 355.

Katz, E. (1960). Biogenesis of the actinomycins. Ann. N.Y. Acad. Sci. 89, 304.

KATZ, E. \& WEISsbach, H. (1962). Effect of chloromycetin and penicillin on the incorporation of amino-acids into actinomycin and protein by Streptomyces antibioticus. Biochem. Biophys. Res. Com. 8, 186.

KATz, E. \& WeissbaCH, H. (1963). Incorporation of ' $\mathrm{C}$ ' labelled amino-acids into actinomycin and protein by Streptomyces antibioticus. J. biol. Chem. 238, 666.

Katz, E., Wise, M. \& Weissbach, H. (1965). Actinomycin biosynthesis. Differential effect of chloramphenicol on protein and peptide antibiotic synthesis. J. biol. Chem. 240, 3071.

KIRK, J. M. (1960). The mode of action of actinomycin D. Biochim. Biophys. Acta, 42, 167.

Lowry, O. H., Rosebrough, N. J., Farr, A. L. \& Randall, R. J. (1951). Protein measurement with the Folin phenol reagent. J. biol. Chem. 193, 265.

Mach, B., Reich, E. \& Tatum, E. L. (1963). Separation of the biosynthesis of the antibiotic polypeptide tyrocidine from protein biosynthesis. Proc. natn. Acad. Sci. U.S.A. 50,175 . 
MACH, B. \& 'TATUM, E. L. (1964). Environmental control of amino acid substitutions in the biosynthesis of the antibiotic polypeptide tyrocidine. Proc. natn. Acad. Sci. U.S.A. 52, 876.

MatTick, A. T. R. \& Hirsch, A. (1947). Further observation on an inhibitory substance (Nisin) from lactic streptococci. Lancet, ii, 5.

Niven, C. F. Jun. (1944). Nutrition of Streptococcus lactis. J. Bact. 47, 343.

Okuda, K., Edwards, G. C., \& Winnick T. (1963). Biosynthesis of gramicidin and tyrocidine in the Dubos strain of Bacillus brevis. J. Bact. 85, 329.

Okuda, K., Uemura, I., Bodley, J. W. \& Winnick, T. (1964). Further aspects of gramicidin and tyrocidine biosynthesis in the cell-free system of Bacillus brevis. Biochemistry, 3, 108.

Park, J. T. \& Hancock, R. (1960). A fractionation procedure for studies of the synthesis of cell-wall mucopeptide and of other polymers in cells of Staphylococcus aureus. J. gen. Microbiol. 22, 249.

Paulus, H. \& Gray, E. (1964). The biosynthesis of polymixin B by growing cultures of Bacillus polymyxa. J. biol. Chem. 239, 865.

SANGER, F. (1959). Chemistry of insulin. Science, 129, 1340.

Sedat, J. W. \& Hall, J. W. (1965). Gramicidin S messenger RNA. II. Physical and chemical properties. J. mol. Biol. $12,174$.

Sells, B. H. (1965). Puromycin: Effect on messenger RNA synthesis and $\beta$-galactosidase formation in Escherichia coli $15 \mathrm{~T}$. Science, 148, 371.

Shimura, K., Sasaki, T. \& Sugawara, K. (1964). Biosynthesis of bacitracin, I. Formation of bacitracin by a subcellular fraction of Bacillus licheniformis. Biochim. Biophys. Acta, 86, 46.

SNOKE, J. E. (1961). Formation of bacitracin by protoplasts of Bacillus licheniformis. J. Bact. 81, 987.

Strominger, J. L. (1962). Biosynthesis of bacterial cell walls. Fed. Proc. $21,134$.

Sypherd, P. S. \& Strauss, N. (1963). Chloramphenicol promoted repression of $\beta$-galactosidase synthesis in Escherichia coli. Proc. natn. Acad. Sci. U.S.A. 49, 400.

Uemura, I., OKuda, K. \& Winnick, T., (1963). Biosynthesis of gramicidins and tyrocidines in cell-free preparations from Bacillus brevis. Biochemistry, 2, 719.

Uemura, I., Bodley, J. W., Adrga, R. P. \& Winnick, T. (1965). Effect of antibiotics and ribonuclease on polypeptide and protein synthesis in different strains of Bacillus brevis. Biochim. Biophys. Acta, 95, 86.

WINNICK, R. E. \& WInnICK, T. (1961). Biosynthesis of gramicidin S. II. Incorporation experiments with labelled amino-acids analogues, and the amino-acid activation process. Biochim. Biophys. Acta, 53, 461.

Winnick, R. E., LIs, H. \& Winnick, T. (1961). Biosynthesis of gramicidin S. I. General characteristics of the process in growing cultures of Bacillus brevis. Biochim. Biophys. Acta, 49, 451.

Yukioka, M., Tsukamoto, Y., Yoshitaka, S., Takitaro, T., Shuzo, O. \& Shohei, O. (1965). Biosynthesis of gramicidin $\mathrm{S}$ by a cell-free system of Bacillus brevis. Biochim. Biophys. Res. Com. 19, 204. 